\title{
Regulation of the lactose phosphotransferase system of Streptococcus bovis by glucose: independence of inducer exclusion and expulsion mechanisms
}

\author{
Gregory M. Cook, ${ }^{1}$ Daniel B. Kearns, ${ }^{1}$ James B. Russell, ${ }^{1,2}$ \\ Jonathan Reizer ${ }^{3}$ and Milton H. Saier, $\mathrm{Jr}^{3}$
}

Author for correspondence: James B. Russell (Cornell University). Tel: +1607255 4508. Fax: +1607255 3904. e-mail: JBR8@cornell.edu

1,2 Section of Microbiology, Cornell University ${ }^{1}$ and Agricultural Research Service, USDA ${ }^{2}$, Ithaca, NY 14853, USA

3 Department of Biology, University of California at San Diego, La Jolla, California 92093-0116, USA
Streptococcus bovis had a diauxic pattern of glucose and lactose utilization, and both of these sugars were transported by the sugar phosphotransferase system (PTS). Lactose catabolism was inducible, and S. bovis used the tagatose pathway to ferment lactose. Since a mutant that was deficient in glucose PTS activity transported lactose as fast as the wild-type, it appeared that S. bovis has separate enzyme lls for glucose and lactose. The nonmetabolizable glucose analogue 2-deoxyglucose (2-DG) was a noncompetitive inhibitor of methyl $\beta$-Dthiogalactopyranoside (TMG) transport, and cells that were provided with either glucose or 2-DG were unable to transport TMG or lactose. Because the glucose-PTS-deficient mutant could ferment glucose, but could not exclude TMG, it appeared that enzyme IIGIC rather than glucose catabolism per se was the critical feature of inducer exclusion. Cells that had accumulated TMG as TMG 6-phosphate expelled free TMG when glucose was added, but 2-DG was unable to cause TMG expulsion. The glucose-PTS-deficient mutant could still expel TMG in the presence of exogenous glucose. Membrane vesicles also exhibited glucose-dependent TMG exclusion and TMG expulsion. Membrane vesicles that were electroporated with phosphoenolpyruvate (PEP) and HPr retained TMG for more than 3 min, but vesicles that were electroporated with PEP plus HPr and fructose 1,6-diphosphate (FDP) (or glycerate 2-phosphate) lost their ability to retain TMG. Because FDP was able to trigger the ATP-dependent phosphorylation of HPr, it appeared that inducer expulsion was mediated by an FDP-activated protein kinase. This conclusion was further supported by the observation that mutant forms of HPr differed in their ability to faciliate inducer expulsion. S46DHPr, a mutant HPr with aspartate substituted for serine at position 46, promoted TMG expulsion from membrane vesicles in the absence of FDP better than wild-type HPr or S46AHPr, a mutant form with alanine substituted for serine at position 46 . Based on these results, it appeared that glucose catabolism was needed for inducer expulsion, but not inducer exclusion.

Keywords: phosphotransferase system, lactose transport, Streptococcus bovis, rumen, inducer exclusion and expulsion
Abbreviations: 2-DG, 2-deoxyglucose; FDP, fructose 1,6-diphosphate; $\mathrm{P}$ - $\beta$-galactosidase, $\beta$-D-phosphogalactoside galactohydrolase; PEP, phosphoenolpyruvate; PTS, phosphotransferase system; TMG, methyl $\beta$-Dthiogalactopyranoside.

\section{INTRODUCTION}

Streptococcus bovis is an opportunistic bacterium that outgrows other ruminal bacteria when there is an abundance of fermentable carbohydrate (Hungate $e t$ al., 
1952). The overgrowth of $S$. bovis results in an accumulation of lactic acid in the rumen, a decrease in ruminal $\mathrm{pH}$, acute indigestion, and even death of the animal (Slyter, 1976). S. bovis can be a significant inhabitant of the human colon (Darjee \& Gibb, 1994). Increased faecal counts of $S$. bovis have been correlated with colon cancer (McMahon et al., 1991), and S. bovis-mediated septicaemia has been used as an index of gut wall deterioration (Reynolds et al., 1983).

The overgrowth of $S$. bovis in the rumen can be explained by its capacity to ferment starch (Slyter, 1976; Russell \& Robinson, 1984), but the proliferation of $S$. bovis in the human colon has yet to be explained. It should be noted that all $S$. bovis strains grow rapidly on lactose (Hardie, 1986), and both colon cancer and lactose intolerance are late-onset human diseases (Reynolds et al., 1983). Gilbert \& Hall (1987) reported that $S$. bovis strain HA3 had $\beta$ galactosidase activity and a lac operon similar to those of Escherichia coli, but many lactic acid bacteria use the phosphoenolpyruvate-phosphotransferase system (PEPPTS) to transport and phosphorylate lactose (Reizer, 1989; Postma et al., 1993).

The lactose PTSs of low-G + C Gram-positive bacteria are regulated by glucose-mediated inducer exclusion and inducer expulsion (Reizer \& Panos, 1980; Thompson \& Saier, 1981; Reizer et al., 1983; Reizer \& Peterkofsky, 1987; Reizer, 1989). In Streptococcus pyogenes (Reizer \& Panos, 1980; Reizer et al., 1983) and Lactococcus lactis (Thompson \& Saier, 1981), glucose prevents the uptake of the nonmetabolizable lactose analogue methyl $\beta$-Dthiogalactopyranoside (TMG), and the addition of glucose causes TMG expulsion. Inducer expulsion in L. lactis has been shown to be caused by a glucose-dependent increase in fructose 1,6-diphosphate (FDP) and a subsequent cascade of phosphorylation and dephosphorylation (Ye et al., 1994). When intracellular FDP concentrations increase, an ATP-dependent protein kinase is allosterically activated, and this protein kinase then phosphorylates HPr, a non-sugar-specific component of the PTS. The phosphorylation of HPr at serine 46 is thought to activate a sugar phosphate phosphatase that dephosphorylates TMG 6-phosphate (Ye et al., 1994). The dephosphorylation of TMG 6-phosphate then facilitates TMG expulsion.

Preliminary experiments indicated that at least 20 strains of $S$. bovis have a PTS for lactose transport (D. B. Kearns, G. M. Cook \& J. B. Russell, unpublished results). The experiments described here were designed to delineate mechanisms of lactose utilization and transport in $S$. bovis. Because $S$. bovis has two systems of glucose transport, a PTS (Martin \& Russell, 1987) and a facilitated diffusion mechanism (Russell, 1990; Cook \& Russell, 1994), we felt that this bacterium might provide additional information on the mechanisms of glucose-dependent inducer exclusion and expulsion.

\section{METHODS}

Materials. All chemicals were analytical reagent grade. $\left[{ }^{14} \mathrm{C}\right]$ Methyl $\beta$-D-thiogalactopyranoside $\left(\left[{ }^{14} \mathrm{C}\right] \mathrm{TMG}\right)$ was obtained from Amersham.

Cell growth. Streptococcus bovis JB1 was grown anaerobically at $39^{\circ} \mathrm{C}$ in basal medium containing (per litre): $292 \mathrm{mg} \mathrm{K} \mathrm{HPO}_{4}$, $292 \mathrm{mg} \mathrm{KH} \mathrm{PO}_{4}, 480 \mathrm{mg}\left(\mathrm{NH}_{4}\right)_{2} \mathrm{SO}_{4}, 480 \mathrm{mg} \mathrm{NaCl}, 100 \mathrm{mg}$ $\mathrm{MgSO}_{4} \cdot 7 \mathrm{H}_{2} \mathrm{O}, 64 \mathrm{mg} \mathrm{CaCl} \cdot 2 \mathrm{H}_{2} \mathrm{O}, 600 \mathrm{mg}$ cysteine hydrochloride, $1 \mathrm{~g}$ Trypticase (BBL Microbiology Systems) and $0.5 \mathrm{~g}$ yeast extract. Carbon sources and glucose analogues were all prepared anoxically and added from separately sterilized stock solutions to the desired final concentration. A glucose-PTSdeficient mutant (JB1 ${ }^{2 \mathrm{DG}}$ ) was isolated as previously described (Cook \& Russell, 1994). The medium was adjusted to $\mathrm{pH} 6 \cdot 7$ and the final $\mathrm{pH}$ was never less than 6.5. The incubation temperature was $39^{\circ} \mathrm{C}$. Growth was monitored by the increase in turbidity $(1 \mathrm{~cm}$ cuvette, $600 \mathrm{~nm}$ ). The relationship between optical density and cell protein was $160 \mathrm{mg}$ protein $1^{-1}$ per $\mathrm{OD}_{600}$ unit.

Toluene-treated cells. Cells $(10 \mathrm{ml})$ were harvested during exponential growth $\left(\mathrm{OD}_{600}\right.$ approximately 1.0$)$ by centrifugation $\left(10000 \mathrm{~g}, 10 \mathrm{~min}, 4^{\circ} \mathrm{C}\right)$ and washed twice in $50 \mathrm{mM}$ Tris/ $\mathrm{HCl}\left(\mathrm{pH} \mathrm{7.0)}\right.$ buffer containing $5 \mathrm{mM} \mathrm{MgCl}_{2}$ and $2 \mathrm{mM}$ dithiothreitol. Cells were then resuspended in $2 \mathrm{ml}$ of the same buffer and stored on ice. The cell suspension $(500 \mu \mathrm{l})$ was treated with $15 \mu \mathrm{l}$ toluene/ethanol $(1: 9, \mathrm{v} / \mathrm{v})$ as previously described (Kornberg \& Reeves, 1972; Martin \& Russell, 1986).

PTS and glucokinase activity. PTS and glucokinase activities were determined in toluene-treated cells at $39^{\circ} \mathrm{C}$ as previously described (Martin \& Russell, 1986). Specific activities were determined under first-order conditions (activity versus protein concentration was linear). All assays were performed in duplicate with appropriate controls. The replicates differed by less than $5 \%$. Where available, commercial enzymes were used as a positive control.

\begin{abstract}
$\boldsymbol{\beta}$-Galactosidase and $\boldsymbol{\beta}$-D-phosphogalactoside galactohydrolase ( $\mathbf{P}-\boldsymbol{\beta}$-galactosidase) assays. To test for the presence of $\beta$-galactosidase (EC 3.2.1.23) in growing cells, cultures samples $(1.0 \mathrm{ml})$ were removed, toluene-treated (as above), and assayed for the release of 0 -nitrophenol from 0 -nitrophenyl $\beta$-Dgalactoside (ONPG) in an assay $\operatorname{mix}(500 \mu \mathrm{l})$ containing $50 \mathrm{mM}$ Tris/ $\mathrm{HCl}\left(\mathrm{pH} \mathrm{7.0}\right.$ ) buffer, $5 \mathrm{mM} \mathrm{MgCl}_{2}$ and $2 \mathrm{mM}$ dithiothreitol. Incubation was at $39^{\circ} \mathrm{C}$ for $5 \mathrm{~min}$ and the reaction was stopped with $500 \mu \mathrm{l} \mathrm{Na}_{2} \mathrm{CO}_{3}$. After $10 \mathrm{~min}$, the assay tubes were centrifuged at $8000 \mathrm{~g}$ for $5 \mathrm{~min}$ at room temperature, and the $A_{420}$ of the supernatant was read. One $A_{420}$ unit was equivalent to $0.52 \mu \mathrm{mol} o$-nitrophenol and was proportional to the quantity of cells in the assay mixture. The assay for P- $\beta$-galactosidase measured the release of 0 -nitrophenol from ONPG 6-phosphate under the same conditions.
\end{abstract}

Preparation of membrane vesicles. Membrane vesicles of $S$. bovis were prepared as previously described (Russell et al., 1988). These vesicles possessed only $22 \%$ of the cellular $\mathrm{HPr}$ activity, but they retained substantial activities of the membraneassociated $\mathrm{HPr}(\mathrm{Ser})$ kinase and $\mathrm{HPr}(\operatorname{Ser}-\mathrm{P})$ phosphatase.

Transport of radioactively labelled sugars. Cells were harvested by centrifugation $\left(10000 \mathrm{~g}, 5 \mathrm{~min}, 4^{\circ} \mathrm{C}\right)$, washed twice in anaerobic buffer $(50 \mathrm{mM}$ Tris $/ \mathrm{HCl}, \mathrm{pH} 7 \cdot 0$, containing $5 \mathrm{mM} \mathrm{MgCl}_{2}$ and $2 \mathrm{mM}$ dithiothreitol, under $\mathrm{N}_{2}$ ), and incubated (approximately $80 \mathrm{mg}$ protein in $200 \mu \mathrm{l}$ ) anaerobically with $\left[{ }^{14} \mathrm{C}\right] \mathrm{TMG}$ (final concentration $60 \mu \mathrm{M}$ ). Transport was terminated by the addition of $2 \mathrm{ml}$ ice-cold $0 \cdot 1 \mathrm{M} \mathrm{LiCl}$ to the 
reaction mixture and rapid filtration through $0.45 \mu \mathrm{m}$ pore size cellulose nitrate membrane filters. Filters were washed with $2 \mathrm{ml}$ $0 \cdot 1 \mathrm{M} \mathrm{LiCl}$, dried for $20 \mathrm{~min}$ at $120^{\circ} \mathrm{C}$, and radioactivity was determined by liquid scintillation counting. The transport kinetics were first order (activity versus protein was linear).

Preparation of TMG 6-phosphate-loaded cells. The preloading buffer $(200 \mu \mathrm{l})$ contained $50 \mathrm{mM}$ Tris $/ \mathrm{HCl}$ buffer $(\mathrm{pH} \mathrm{7 \cdot 0})$, $5 \mathrm{mM}$ dithiothreitol, $5 \mathrm{mM} \mathrm{MgCl}{ }_{2}$, $\left[{ }^{14} \mathrm{C}\right] \mathrm{TMG}$ (final concentration $60 \mu \mathrm{M}$ ), and 5-10 mg $S$. bovis protein (cells or vesicles). After incubation for $10 \mathrm{~min}$ at $39^{\circ} \mathrm{C}$, after which time the maximal accumulation of TMG 6-phosphate had been achieved, the cells were used in expulsion studies as described in Results. The radioactive material in the cells and vesicles was shown to consist of $\left[{ }^{14} \mathrm{C}\right] \mathrm{TMG}$ 6-phosphate as determined by ionexchange chromatography $(5 \times 0.5 \mathrm{~cm}$ column size) according to Kundig \& Roseman (1971).

Electroporation of $\mathrm{HPr}$ and metabolites into membrane vesicles of S. bovis. Bacillus subtilis $\mathrm{HPr}(50 \mu \mathrm{M})$ or one of the mutant proteins S46AHPr or S46DHPr (also $50 \mu \mathrm{M}$ ) (Reizer et al., 1989) were added to a gene pulser cuvette (Bio-Rad) containing $100 \mu \mathrm{l} S$. bovis vesicles (10 $\mathrm{mg}$ protein). The mixture was then electroporated twice at $0^{\circ} \mathrm{C}$ and $700 \mathrm{~V}$ (resistance $200 \Omega$; capacitance $25 \mu \mathrm{F}$ ) for $1.5 \mathrm{~ms}$. The mixture was left on ice for $20 \mathrm{~min}$ before the electroporated vesicles were used for TMG uptake as described above.

Assay of ATP-dependent phosphorylation of HPr by a protein kinase in membrane vesicles of $\mathbf{S}$. bovis. The assay mixture for $\mathrm{HPr}(\mathrm{Ser})$ phosphorylation $(50 \mu \mathrm{l}$ final volume) contained $50 \mathrm{mM}$ Tris/ $\mathrm{HCl}$ buffer ( $\mathrm{pH} \mathrm{7.0}), 5 \mathrm{mM}$ dithiothreitol, $5 \mathrm{mM}$ $\mathrm{MgCl}_{2}, \quad 1.0 \mathrm{mM}\left[\gamma_{-}{ }^{32} \mathrm{P}\right]$ ATP (ICN Pharmaceuticals; $500-$ 2000 c.p.m. pmol $^{-1}$ ), $50 \mu \mathrm{M} \mathrm{HPr}$ and $5 \mathrm{mg}$ vesicle protein. Various sugars and sugar metabolites were also present as indicated in Results. The assay mixture was electroporated as indicated and incubated for $30 \mathrm{~min}$ at $39^{\circ} \mathrm{C}$ before the reaction was terminated by the addition of SDS quench buffer. Proteins were separated by SDS-gel electrophoresis (Laemmli, 1970; Reizer et al., 1988); the gels were stained for proteins with Coomassie Blue $\mathrm{R}$ in $25 \%$ methanol, $10 \%$ acetic acid (v/v) $(1 \mathrm{~h}$ at $\left.55^{\circ} \mathrm{C}\right)$, and then destained with the same solvent $(4 \mathrm{~h}$ at $55^{\circ} \mathrm{C}$ ), before drying under reduced pressure. Radioactivity in the dry gels was determined by autoradiography.

Other analyses. Glucose was analysed by an enzymic method using hexokinase and glucose-6-phosphate dehydrogenase (Bergmeyer \& Klotsch, 1965). Lactose was assayed by converting lactose to glucose using $\beta$-galactosidase followed by enzymic determination of glucose. Protein from $\mathrm{NaOH}$ hydrolysed cells $\left(0 \cdot 2 \mathrm{M} \mathrm{NaOH}, 100^{\circ} \mathrm{C}, 15 \mathrm{~min}\right)$ was assayed by the Lowry method. Galactokinase and galactose-6-phosphate isomerase were assayed as described by Crow et al. (1983).
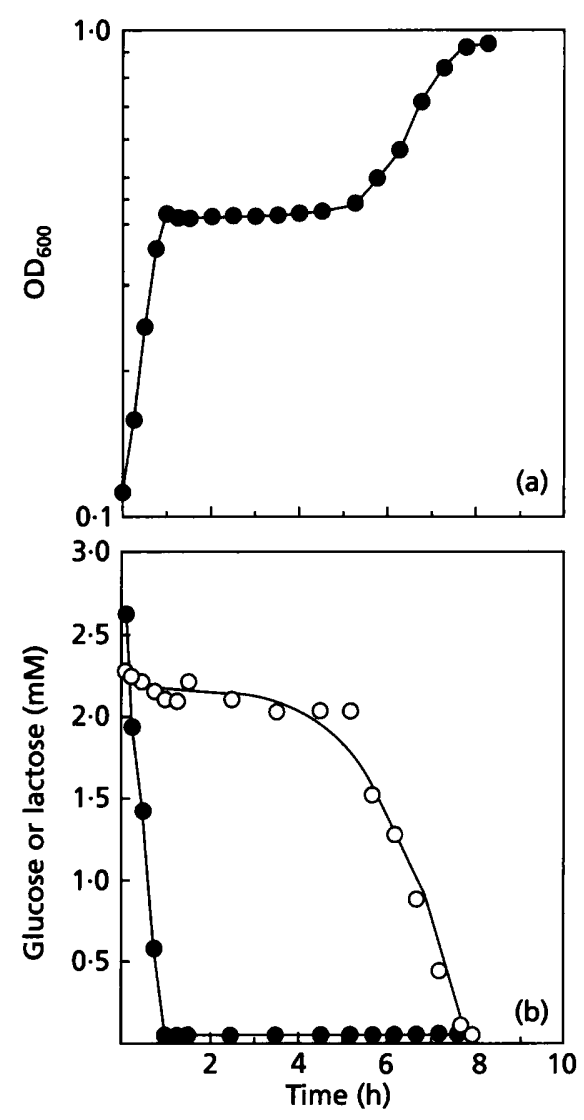

Fig. 1. (a) Growth and (b) utilization of sugars (O, glucose; $O$, lactose) by $S$. bovis grown on glucose plus lactose. Cells were pre-grown on glucose.

\section{RESULTS}

\section{Glucose and lactose transport by S. bovis}

S. bovis JB1 grew rapidly on glucose or lactose, but the maximal specific growth rate was always lower with lactose than with glucose (Table 1). Cells grown on either glucose or lactose had high rates of PEP-dependent glucose phosphorylation, but lactose PTS activity was very low unless lactose was the energy source. Cells which were successively transferred on glucose plus 2-DG lost most of their glucose PTS activity $\left(\mathrm{JB} 1^{2 \mathrm{DG}}\right)$, but were still able to grow rapidly on glucose or lactose (Table 1 ). The

Table 1. Glucose and lactose utilization by $S$. bovis

\begin{tabular}{|lcccccc|}
\hline Strain & $\begin{array}{c}\text { Growth } \\
\text { substrate }\end{array}$ & $\begin{array}{c}\text { Growth } \\
\text { rate } \\
\left(\mathbf{h}^{-1}\right)\end{array}$ & $\begin{array}{c}\text { Glucose } \\
\text { PTS* }\end{array}$ & $\begin{array}{c}\text { Lactose } \\
\text { PTS* }\end{array}$ & $\begin{array}{c}\boldsymbol{\beta} \text {-Galactosidase } \\
\text { activity* }\end{array}$ & $\begin{array}{c}\text { P- } \boldsymbol{\beta} \text {-Galactosidase } \\
\text { activity* }\end{array}$ \\
\hline JB1 & Glucose & $1 \cdot 85$ & $996 \cdot 0 \pm 63 \cdot 0$ & $10 \cdot 0 \pm 3 \cdot 0$ & $8 \cdot 0 \pm 6 \cdot 0$ & $12 \cdot 0 \pm 4 \cdot 0$ \\
& Lactose & $0 \cdot 85$ & $953 \cdot 0 \pm 40 \cdot 0$ & $415 \cdot 0 \pm 29 \cdot 0$ & $15 \cdot 3 \pm 7 \cdot 1$ & $908 \cdot 0 \pm 65 \cdot 0$ \\
JB1 ${ }^{2 \mathrm{DG}}$ & Glucose & $1 \cdot 75$ & $33 \cdot 0 \pm 5 \cdot 0$ & $20 \cdot 0 \pm 4 \cdot 0$ & $15 \cdot 0 \pm 3 \cdot 8$ & $20 \cdot 0 \pm 6 \cdot 4$ \\
& Lactose & $0 \cdot 80$ & $16 \cdot 0 \pm 3 \cdot 0$ & $403 \cdot 0 \pm 41 \cdot 0$ & $8 \cdot 0 \pm 2 \cdot 2$ & $1004 \cdot 0 \pm 80 \cdot 0$ \\
\hline
\end{tabular}

* All activities are expressed as nmol substrate converted to product per min per mg protein by toluenetreated cells at $39^{\circ} \mathrm{C}$. Results are the means of duplicates, \pm range. 

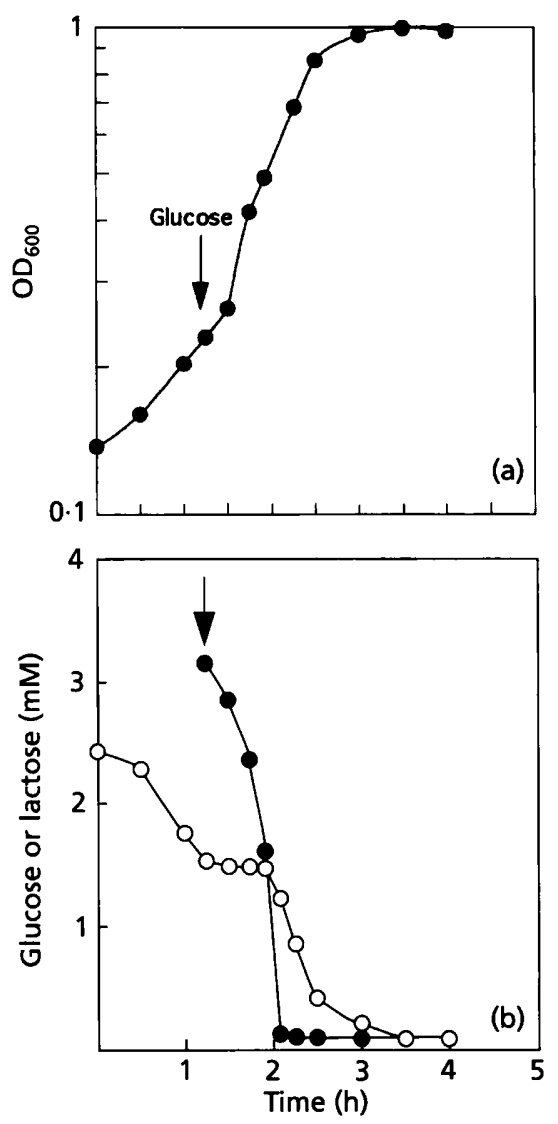

Fig. 2. Effect of glucose addition (as indicated by the arrow) on lactose utilization by cultures of $S$. bovis growing on lactose. (a) Growth; (b) utilization of glucose (O) and lactose (O). Cells were pre-grown on lactose.

wild-type strain and strain $\mathrm{JB} 1^{2 \mathrm{DG}}$ had approximately the same lactose PTS activity when lactose was the energy source for growth. Toluene-treated cells that had been grown on lactose hydrolysed ONPG, but the rate of ONPG hydrolysis was more than 20 -fold less than the rate of lactose phosphorylation via the PTS (Table 1 ). The rate of ONPG 6-phosphate hydrolysis was 50-fold greater than that of ONPG, and the cells also had an inducible galactose-6-phosphate isomerase $\left[335.71 \mathrm{nmol} \mathrm{min}{ }^{-1}(\mathrm{mg}\right.$ protein $\left.)^{-1}\right]$. Little, if any, galactokinase activity was detected $\left[<20 \mathrm{nmol} \mathrm{min}^{-1}(\mathrm{mg} \text { protein })^{-1}\right]$. Lactose transport could not be driven by an artificial membrane potential $(\Delta \Psi)$ or $\mathrm{pH}$ gradient $(\mathrm{Z} \Delta \mathrm{pH})$, and the protonophore 3,3',4',5-tetrachlorosalicylanide (TCS) and the sodium/proton antiporter monensin had no effect on the rate of lactose fermentation by washed cells (data not shown).

\section{Inducer exclusion and expulsion in intact S. bovis cells}

When $S$. bovis cells that had been pre-grown on glucose were provided with a combination of glucose and lactose, a diauxic growth pattern was observed (Fig. 1). Glucose

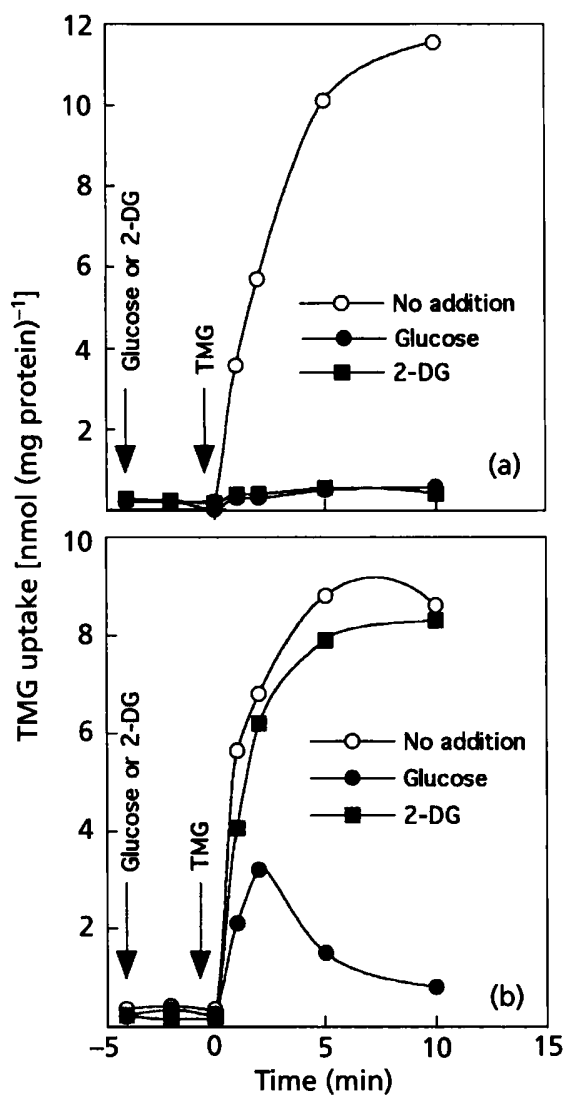

Fig. 3. Effect of glucose or 2-DG addition on the uptake of $\left[{ }^{14} \mathrm{C}\right]$ TMG by whole cells of $S$. bovis JB1 (a) and a PTS-deficient mutant JB1 $2 \mathrm{DG}$ (b). Glucose or 2-DG (final concentration $20 \mathrm{mM}$ ) were added $4 \mathrm{~min}$ prior to $\left[{ }^{14} \mathrm{C}\right] \mathrm{TMG}(60 \mu \mathrm{M}$ final concentration) addition.

was used preferentially to lactose and no lactose utilization was noted until the glucose was depleted from the growth medium. Cells that had been pre-grown on lactose exhibited a short lag phase when transferred to medium containing lactose (Fig. 2). Glucose addition to cultures growing on lactose immediately inhibited lactose uptake and lactose uptake did not continue until glucose was completely utilized (Fig. 2).

Washed cells of S. bovis JB1 grown on lactose transported $\left[{ }^{14} \mathrm{C}\right] \mathrm{TMG}$ or $\left[{ }^{14} \mathrm{C}\right]$ lactose at a rapid rate (data not shown). No $\left[{ }^{14} \mathrm{C}\right] \mathrm{TMG}$ or $\left[{ }^{14} \mathrm{C}\right]$ lactose uptake was noted if the cells were grown on glucose. Rapid transport of $\left[{ }^{14} \mathrm{C}\right]$ glucose or $2-\left[{ }^{14} \mathrm{C}\right] \mathrm{DG}$ was observed whether the cells were grown on glucose or lactose (data not shown). The nonmetabolizable sugars 2-DG and TMG were competitive inhibitors of glucose and lactose uptake, respectively (data not shown). When glucose or 2-DG was added to lactose-grown cells prior to the addition of $\left[{ }^{14} \mathrm{C}\right] \mathrm{TMG}$, $\left[{ }^{14} \mathrm{C}\right] \mathrm{TMG}$ uptake was completely blocked (Fig. 3a). The Lineweaver-Burk plot of $\left[{ }^{14} \mathrm{C}\right] \mathrm{TMG}$ uptake in the presence of unlabelled 2-DG indicated that 2-DG was a noncompetitive inhibitor of TMG transport (data not shown). 


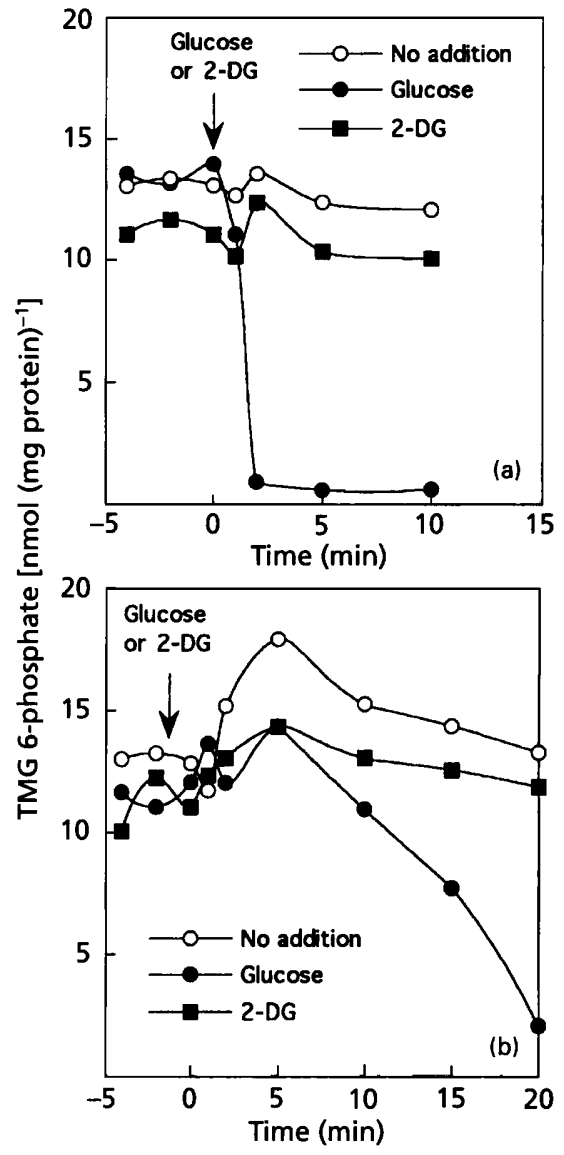

Fig. 4. Effect of glucose or 2-DG addition on the efflux of $\left[{ }^{14} \mathrm{C}\right]$ TMG from whole cells of $S$. bovis JB1 (a) and a PTS-deficient mutant JB12DG (b) loaded with $\left[{ }^{14} \mathrm{C}\right] \mathrm{TMG}$ 6-phosphate. Cells were loaded with $\left[{ }^{14} \mathrm{C}\right] \mathrm{TMG}(60 \mu \mathrm{M}$ final concentration) for $10 \mathrm{~min}$ prior to glucose or 2-DG addition (final concentration $20 \mathrm{mM})$.

The PTS-deficient mutant strain JB1 ${ }^{2 D G}$ (defective in enzyme II ${ }^{\mathrm{Glc}}$ ) grew rapidly on glucose, but it had very low rates of PEP-dependent glucose or 2-DG phosphorylation (Table 1). When JB1 ${ }^{2 \mathrm{DG}}$ was pre-incubated with 2-DG prior to $\left[{ }^{14} \mathrm{C}\right]$ TMG addition, there was no effect on $\left[{ }^{14} \mathrm{C}\right]$ TMG uptake (Fig. 3b). If glucose was added, $\left[{ }^{14} \mathrm{C}\right] \mathrm{TMG}$ was still transported, but after $2 \mathrm{~min}$ the rate of $\left[{ }^{14} \mathrm{C}\right] \mathrm{TMG}$ accumulation decreased. These results were consistent with the idea that glucose catabolism causes $\left[{ }^{14} \mathrm{C}\right] \mathrm{TMG}$ expulsion, but not exclusion.

Wild-type cells incubated with $\left[{ }^{14} \mathrm{C}\right] \mathrm{TMG}$ retained $\left[{ }^{14} \mathrm{C}\right] \mathrm{TMG}$ as the phosphate ester, TMG 6-phosphate, for more than $10 \mathrm{~min}$ as determined by ion-exchange chromatography. The addition of glucose to TMG-6phosphate-loaded cells caused immediate efflux of free TMG (not TMG 6-phosphate), but the addition of 2-DG had no effect (Fig. 4a). Glucose addition also caused expulsion of $\left[{ }^{14} \mathrm{C}\right]$ TMG from TMG-6-phosphate-loaded cells of JB1 ${ }^{2 D G}$ (Fig. 4b), but the rate of expulsion was slow compared with that in wild-type cells. 2-DG had no effect on TMG expulsion from $\mathrm{JB} 1^{2 \mathrm{DG}}$.

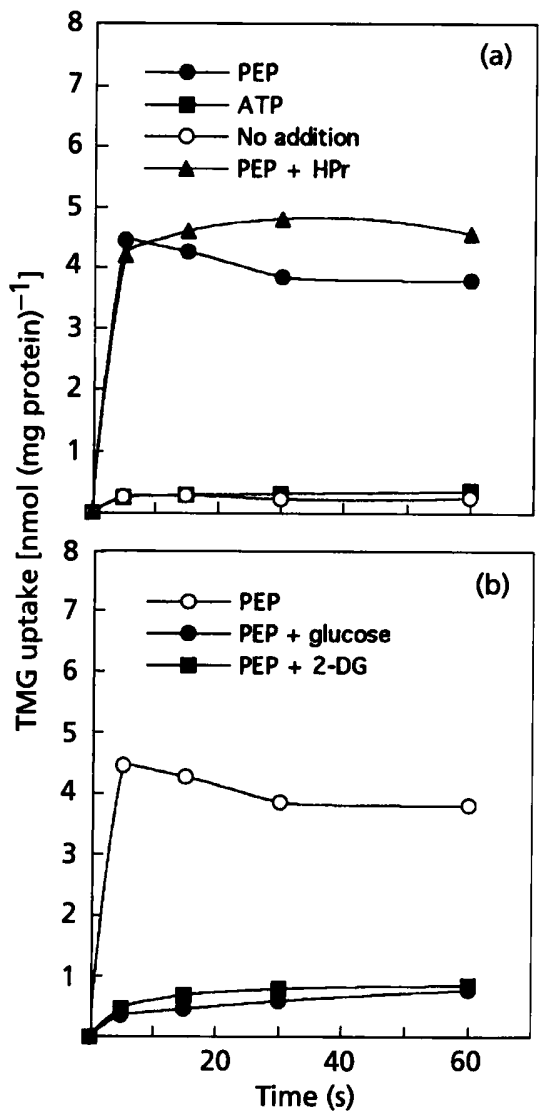

Fig. 5. $\left[{ }^{14} \mathrm{C}\right]$ TMG uptake by membrane vesicles of $S$. bovis JB 1 in the absence (a) and presence (b) of glucose or 2-DG. Membrane vesicles were prepared from lactose-grown cells and electroporated in the presence of $20 \mathrm{mM}$ PEP (with or without $100 \mu \mathrm{M} \mathrm{HPr}$ ) or $20 \mathrm{mM}$ ATP. Controls were electroporated in the absence of any added compound. Glucose and 2-DG (final concentration $20 \mathrm{mM}$ ) were added (extravesicularly) 2 min prior to $\left[{ }^{14} \mathrm{C}\right] \mathrm{TMG}$ (60 $\mu \mathrm{M}$ final concentration) addition.

\section{Regulation of TMG accumulation in S. bovis membrane vesicles}

Membrane vesicles were prepared from lactose-grown cells of wild-type JB1 and tested for their ability to accumulate $\left[{ }^{14} \mathrm{C}\right] \mathrm{TMG}$. When membrane vesicles were incubated with $\left[{ }^{14} \mathrm{C}\right] \mathrm{TMG}$, no uptake was observed, even after $3 \mathrm{~min}$ incubation. However, if the membrane vesicles were first electroporated with $20 \mathrm{mM}$ PEP, rapid rates of $\left[{ }^{14} \mathrm{C}\right] \mathrm{TMG}$ uptake were noted (Fig. 5a). Virtually all of the intravesicular TMG was present as TMG 6-phosphate. Electroporation of the membrane vesicles with ATP did not promote $\left[{ }^{14} \mathrm{C}\right] \mathrm{TMG}$ uptake, and additional HPr did not increase the rate of PEP-dependent TMG uptake (Fig. 5a). Membrane vesicles that were electroporated with PEP and incubated with glucose or 2-DG (extravesicularly) prior to $\left[{ }^{14} \mathrm{C}\right] \mathrm{TMG}$ addition lost their ability to take up $\left[{ }^{14} \mathrm{C}\right]$ TMG (Fig. $5 \mathrm{~b}$ ).

Membrane vesicles accumulated $\left[{ }^{14} \mathrm{C}\right] \mathrm{TMG}$ as TMG 6phosphate, which was retained for more than $3 \mathrm{~min}$, but rapid TMG efflux was observed if glucose was added 


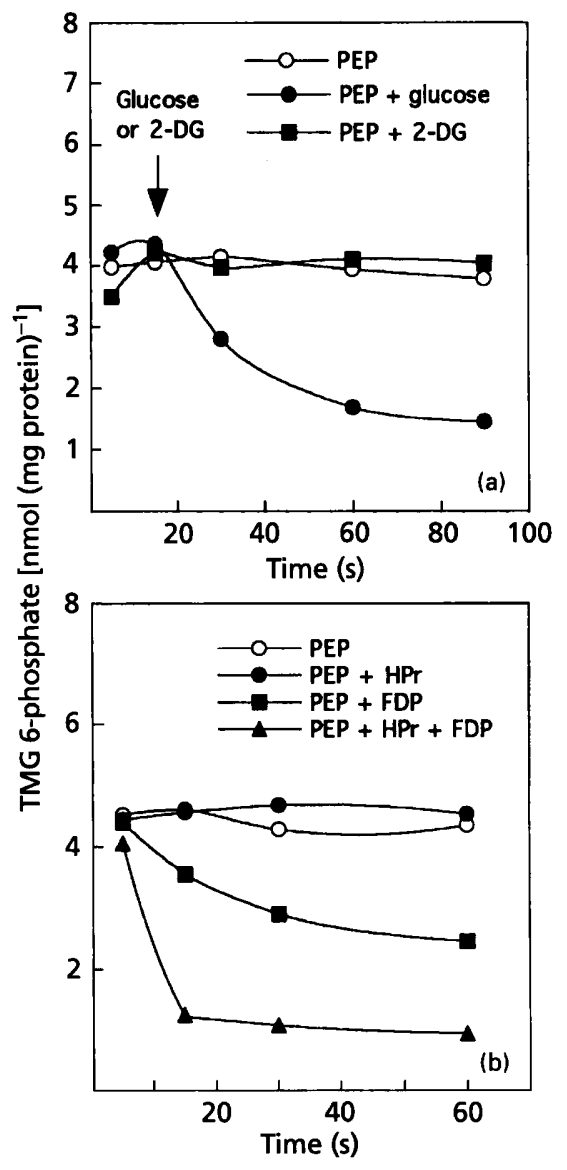

Fig. 6. Efflux of $\left[{ }^{14} \mathrm{C}\right]$ TMG from $\left[{ }^{14} \mathrm{C}\right]$ TMG-6-phosphate-loaded membrane vesicles of $S$. bovis JB1. (a) Effect of glucose or 2-DG addition on efflux. Membrane vesicles were loaded for $15 \mathrm{~s}$ in the presence of $20 \mathrm{mM}$ PEP and $60 \mu \mathrm{M}\left[{ }^{14} \mathrm{C}\right] T \mathrm{MG}$. (b) Effect of intravesicular addition of FDP $(20 \mathrm{mM})$ on the ability of membrane vesicles to retain $\left[{ }^{14} \mathrm{C}\right] \mathrm{TMG}$ 6-phosphate in the presence and absence of $50 \mu \mathrm{M} \mathrm{HPr}$. extravesicularly (Fig. 6a). 2-DG was unable to trigger TMG efflux from membrane vesicles. Membrane vesicles that were electroporated with PEP and FDP were unable to retain TMG 6-phosphate, particularly if additional HPr was also added intravesicularly (Fig. 6b). Intravesicular glycerate 2-phosphate could replace FDP in decreasing TMG 6-phosphate retention, but other glycolytic intermediates were less effective (Table 2).

\section{Demonstration of vesicular HPr phosphorylation}

When HPr, FDP $(20 \mathrm{mM})$ and $1 \mathrm{mM}\left[\gamma^{-32} \mathrm{P}\right]$ ATP were electroporated into the membrane vesicles, followed by incubation at $39^{\circ} \mathrm{C}$ for $30 \mathrm{~min}$, there was an increased rate of $\left[\gamma^{32} \mathrm{P}\right]$ ATP-dependent phosphorylation of $\mathrm{HPr}$ as determined by autoradiography. Gels (SDS-PAGE) stained for proteins with Coomassie Blue $\mathrm{R}$ confirmed that the radioactive spots were indeed $\mathrm{HPr}$ (data not shown). Strong phosphorylation of $\mathrm{HPr}$ was also observed when glycerate 2-phosphate or glucose was added to the electroporation buffer. Little if any $[\gamma-$ $\left.{ }^{32} \mathrm{P}\right]$ ATP-dependent phosphorylation of HPr could be detected if other glycolytic intermediates were added (data not shown). Very little phosphorylation was observed when $\left[\gamma_{-}{ }^{32} \mathrm{P}\right]$ A TP was electroporated into membrane vesicles without $\mathrm{HPr}$ in the presence of glucose. Similarly, when both $\left[\gamma_{-}{ }^{32} \mathrm{P}\right]$ ATP and HPr were electroporated into the vesicles, but glucose or a metabolite of glucose was absent, very little phosphorylation was observed. These latter observations supported the idea that additional intravesicular HPr as well as a metabolite of glucose were needed for strong ATP-dependent phosphorylation of HPr.

\section{Regulation of TMG efflux by serine-46 in HPr}

To demonstrate the possibility that HPr plays a direct role in the regulation of the lactose PTS of $S$. bovis by glucose,

\section{Table 2. Regulation of $\left[{ }^{14} \mathrm{C}\right]$ TMG expulsion from $S$. bovis membrane vesicles}

Membrane vesicles were electroporated in the presence of $20 \mathrm{mM}$ PEP plus $50 \mu \mathrm{M} \mathrm{HPr}$ and the compound listed in the table at a final concentration of $20 \mathrm{mM}$. TMG 6-phosphate remaining in the membrane vesicles was measured after $1 \mathrm{~min}$. All values reported are the means of duplicates, \pm range.

\begin{tabular}{|lcc|}
\hline $\begin{array}{l}\text { Experimental } \\
\text { conditions }\end{array}$ & $\begin{array}{c}\text { TMG 6-phosphate } \\
\text { [nmol } \\
\text { (mg protein) })^{-1} \text { ] }\end{array}$ & $\begin{array}{c}\text { TMG 6-phosphate } \\
\text { retained (\%) }\end{array}$ \\
\hline Control (no metabolite addition) & $4 \cdot 35 \pm 0 \cdot 65$ & 100 \\
Glycerate 2-phosphate & $0 \cdot 78 \pm 0 \cdot 22$ & $17 \cdot 9$ \\
Fructose 1,6-diphosphate (FDP) & $0 \cdot 97 \pm 0 \cdot 16$ & $22 \cdot 2$ \\
Glucose & $1 \cdot 20 \pm 0 \cdot 23$ & $27 \cdot 6$ \\
Fructose 6-phosphate & $1 \cdot 71 \pm 0 \cdot 36$ & $39 \cdot 3$ \\
Fructose 1-phosphate & $1 \cdot 82 \pm 0 \cdot 21$ & $41 \cdot 8$ \\
Glycerate 3-phosphate & $2 \cdot 68 \pm 0 \cdot 16$ & $61 \cdot 6$ \\
Glucose 6-phosphate & $3 \cdot 00 \pm 0 \cdot 27$ & $68 \cdot 9$ \\
Gluconate 6-phosphate & $3 \cdot 32 \pm 0 \cdot 19$ & $76 \cdot 3$ \\
Galactose 6-phosphate & $4 \cdot 01 \pm 0 \cdot 10$ & $92 \cdot 1$ \\
Pyruvate & $4 \cdot 00 \pm 0 \cdot 25$ & $92 \cdot 0$ \\
\hline
\end{tabular}




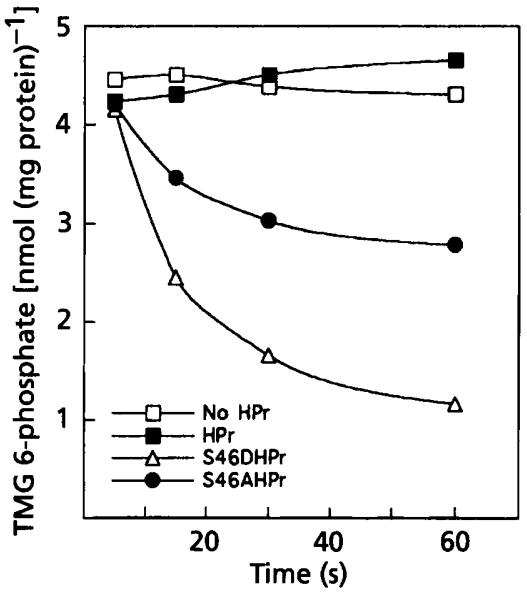

Fig. 7. Effect of intravesicular addition of S46DHPr $(50 \mu \mathrm{M})$ or S46AHPr $(50 \mu \mathrm{M})$ on the ability of $S$. bovis membrane vesicles to retain $\left[{ }^{14} \mathrm{C}\right] \mathrm{TMG}$ 6-phosphate.

site-specific mutant forms of HPr modified in the seryl 46 residue were tested for their ability to cause TMG efflux in membrane vesicles. When S46DHPr, which is conformationally similar to serine-phosphorylated HPr (Reizer et al., 1989), was substituted for wild-type HPr in the electroporation step, the vesicles lost their ability to retain TMG 6-phosphate, even if FDP or another glycolytic intermediate was not present (Fig. 7). S46AHPr, an HPr derivative with a neutral alanyl residue at position 46 , also caused TMG expulsion, but to a lesser extent than S46DHPr.

\section{DISCUSSION}

Many bacteria are able to utilize some energy sources preferentially, and sequential patterns of energy source utilization allow bacteria to minimize protein synthesis and maximize their growth rates (Magasanik, 1961). In E. coli, glucose is the preferred energy source, and the ability of glucose to inhibit other utilizations was originally called the 'glucose effect' (Monod, 1947). In the 1960s, Magasanik (1961) coined the term catabolite repression, and later work indicated that glucose, via cyclic AMP and a catabolite activator protein, regulated the transcription of the lactose operon (Peterkofsky \& Gazdar, 1974). McGinnis \& Paigen (1969) noted that E. coli also had a short-term mechanism of regulating lactose utilization and introduced the term 'catabolite inhibition'. Subsequent work indicated that this latter effect was due to an inhibition of lactose transport by glucose (McGinnis \& Paigen, 1973).

Saier \& Roseman (1976) demonstrated that the glucose PTS of E. coli could inhibit the lac permease, and later work indicated that inducer exclusion was mediated by a direct interaction of enzyme IIA Glc with the permease (Saier, 1985, 1989). In some Gram-positive bacteria, the glucose PTS regulates other PTS systems (Reizer \& Panos, 1980; Thompson \& Saier, 1981; Reizer et al., 1983, 1984) and causes inducer expulsion as well as inducer exclusion. A process analogous to inducer expulsion has been reported in Gram-negative bacteria (Haguenauer \& Kepes, 1971, 1972; Winkler, 1991). In fermentative, low$\mathrm{G}+\mathrm{C}$ Gram-positive bacteria, inducer expulsion involves the action of a sugar phosphate phosphatase that dephosphorylates the sugar prior to its being 'expelled' from the cell (London et al., 1985; Reizer et al., 1983, 1985; Sutrina et al., 1988; Thompson \& Chassy, 1983a, b).

Inducer expulsion was first demonstrated in Streptococcus pyogenes (Reizer \& Panos, 1980), and under these conditions the phosphate carrier protein, $\mathrm{HPr}$, was phosphorylated at seryl residue 46 (Ser 46) as well as its catalytic domain (Deutscher \& Saier, 1983; Reizer et al., 1983). The phosphorylation of HPr at Ser 46 was mediated by an ATP-dependent protein kinase (Deutscher \& Saier, 1983). Because the protein kinase seemed to be allosterically activated by a glucose-dependent increase in FDP, it appeared that $\mathrm{HPr}$ was controlling inducer expulsion (Reizer et al., 1984). This conclusion was supported by the observation that a mutant form of $\mathrm{HPr}$ having a negatively charged aspartyl residue rather than serine at position $46(\mathrm{~S} 46 \mathrm{DHPr})$ triggered the expulsion of the non-metabolizable lactose analogue TMG from membrane vesicles of Lactococcus lactis, even if FDP was not present (Ye et al., 1994). Another mutant of $\mathrm{HPr}$ having a neutral alanyl residue (S46AHPr) was inactive or less effective at triggering expulsion.

In $S$. bovis, lactose was transported by a PEP-dependent mechanism, and there was no evidence that this sugar was taken up by active transport. Because toluene-treated cells could hydrolyse ONPG 6-phosphate, but not ONPG, at a rapid rate, it appeared that the low $\beta$-galactosidase activity observed might be little more than an artifact. When lactose 6-phosphate is converted to glucose and galactose 6-phosphate, the latter is usually fermented by the tagatose pathway (Crow et al., 1983). Because lactose 6-phosphate hydrolase and galactose 6-phosphate isomerase, but not galactokinase activity, could be detected, it is likely that $S$. bovis also uses the tagatose pathway for lactose fermentation.

Because S. bovis had a diauxic pattern of glucose and lactose utilization, and glucose was a noncompetitive inhibitor of TMG uptake, it appeared that the lactose PTS must be regulated by inducer exclusion. The nonmetabolizable glucose analogue 2-DG was able to mediate exclusion to the same extent as glucose. The glucose-PTSdeficient mutant $S$. bovis $\mathrm{JB}^{2 \mathrm{DG}}$ also fermented glucose, but in this case neither glucose nor 2-DG could exclude TMG. Based on these results, it appeared that enzyme II $^{\text {Gle }}$, rather than glucose catabolism per se, was the critical feature of inducer exclusion. In E. coli, enzyme $\mathrm{II}^{\mathrm{Glc}}$ has a higher affinity for phospho-HPr than enzyme $\mathrm{II}^{\mathrm{Mt1}}$, and competition for phospho-HPr allows for the preferential utilization of glucose to the exclusion of mannitol (Saier, 1985). Dills \& Seno (1983) reported that a glucose PTS mutant of Streptococcus mutans lost its ability to exclude hexitols, but the effect of glucose catabolism was not studied. 
Glucose, but not 2-DG, was able to promote the expulsion of TMG from $S$. bovis cells and membrane vesicles, and this result indicated that glucose catabolism was an obligate feature of inducer expulsion. This conclusion is supported by the observation that membrane vesicles could not expel TMG until they were electroporated with FDP, an intermediate in the Embden-Meyerhof pathway of glucose catabolism. The role of FDP in inducer expulsion was further reinforced by the demonstration that FDP was needed to promote the ATP-dependent phosphorylation of HPr in membrane vesicles, and also by the observation that HPr modifications at serine 46 affected both the rate and extent of TMG expulsion from membrane vesicles. Because $\mathrm{S} 46 \mathrm{DHPr}$, an $\mathrm{HPr}$ derivative conformationally similar to serine-phosphorylated $\mathrm{HPr}$, was more effective than S46AHPr at causing TMG efflux, it appears that ATP-dependent phosphorylation of Ser-46 $\mathrm{HPr}$ may play a direct role in inducer expulsion. This conclusion is likewise supported by the finding that the membrane-bound sugar phosphate phosphatase of $S$. bovis is activated by $\mathrm{S} 46 \mathrm{DHPr}$, but not S46AHPr (G. M. Cook, J. J. Ye, J. B. Russell \& M. H. Saier, Jr, unpublished results).

The independence of inducer exclusion and expulsion mechanisms was also illustrated by the comparison of wild-type $S$. bovis and the PTS-deficient mutant JB1 ${ }^{2 D G}$. This mutant lost its ability to exclude TMG, but it retained its capacity to metabolize glucose, produce FDP, and catalyse the ATP-dependent phosphorylation of HPr. Because JB1 ${ }^{2 D G}$ was able to dephosphorylate TMG 6phosphate, TMG uptake was only a transient process when glucose was present.

\section{ACKNOWLEDGEMENTS}

This work was supported by the U.S. Dairy Forage Research Center, Madison, WI and Public Health Service grants 5RO1 AI21702 and 2RO1 AI14176 from the National Institute of Allergy and Infectious Diseases.

Proprietary or brand names are necessary to report factually on available data; however, the USDA neither guarantees nor warrants the standard of the product, and the use of the name by the USDA implies no approval of the product, and exclusion of others that may be suitable.

\section{REFERENCES}

Bergmeyer, H. U. \& Klotsch, H. (1965). Sucrose. In Methods of Envymatic Analysis, pp. 99-102. Edited by H. U. Bergmeyer. New York: Academic Press.

Cook, G. M. \& Russell, J. B. (1994). Alternative strategies of 2deoxyglucose resistance and low affinity glucose transport in the ruminal bacteria, Streptococcus bovis and Selenomonas ruminantium. FEMS Microbiol Lett 123, 207-212.

Crow, V. L., Davey, G. P., Pearce, L. E. \& Thomas, T. D. (1983). Plasmid linkage of the D-tagatose-6-phosphate pathway in Streptococcus lactis: effect on lactose and galactose metabolism. $J$ Bacteriol 153, 76-83.

Darjee, R. \& Gibb, A. P. (1994). Serological investigation into the association between Streptococcus bovis and colonic cancer. J Clin Path 47, 870.
Deutscher, J. \& Saier, M. H., Jr (1983). ATP-dependent protein kinase-catalyzed phosphorylation of a seryl residue in $\mathrm{HPr}$, a phosphate carrier protein of the phosphotransferase system in Streptococcus pyogenes. Proc Natl Acad Sci US A 80, 6790-6794.

Dills, S. S. \& Seno, S. (1983). Regulation of hexitol catabolism in Streptococcus mutans. J Bacteriol 153, 861-866.

Gilbert, H. J. \& Hall, J. (1987). Molecular cloning of Streptococcus bovis lactose catabolic genes. J Gen Microbiol 133, 2285-2293.

Haguenauer, R. \& Kepes, A. (1971). The cycle of renewal of intracellular $\alpha$-methyl-D-glucoside accumulated by the glucose permease of E. coli. Biocbimie 53, 90-107.

Haguenauer, R. \& Kepes, A. (1972). $\mathrm{NaF}$ inhibition of phosphorylation and dephosphorylation involved in $\alpha$-methyl-Dglucoside transport in E. coli K12. A pH dependent phenomenon sensitive to uncoupling agents. Biochimie 54, 505-512.

Hardie, J. M. (1986). Genus Streptococcus. In Bergey's Manual of Systematic Bacteriology, 2nd edn, vol. 2, pp. 1043-1046. Edited by P. H. A. Sneath, N. S. Mair, M. E. Sharpe \& J. G. Holt. Baltimore: Williams \& Wilkins.

Hungate, R. E., Dougherty, R. W., Bryant, M. P. \& Cello, R. M. (1952). Microbiological and physiological changes associated with acute indigestion in sheep. Cornell Vet 42, 423-449.

Kornberg, H. L. \& Reeves, R. E. (1972). Inducible phosphoenolpyruvate-dependent hexose phosphotransferase activities in Escherichia coli. Biochem J 128, 1339-1344.

Kundig, W. \& Roseman, S. (1971). Sugar transport. II. Characterization of constitutive membrane-bound enzymes II of the Escherichia coli phosphotransferase system. J Biol Chem 246, 1407-1418.

Laemmli, U. K. (1970). Cleavage of structural proteins during the assembly of the head of bacteriophage T4. Nature 277, 680-685.

London, J., Hausman, S. Z. \& Thompson, J. (1985). Characterization of a membrane-regulated sugar phosphate phosphohydrolase from Lactobacillus casei. J Bacteriol 163, 951-956.

McGinnis, J. F. \& Paigen, K. (1969). Catabolite inhibition : a general phenomenon in the control of carbohydrate utilization. $J$ Bacteriol 100, 902-913.

McGinnis, J. F. \& Paigen, K. (1973). Site of catabolite inhibition of carbohydrate metabolism. J Bacteriol 114, 885-887.

McMahon, A. J., Auld, C. D., Dale, B. A. S., Walls, A. D. F. \& McCormick, J. StC. (1991). Streptococcus bovis septicaemia associated with uncomplicated colonic carcinoma. Brit J Surg 78, 883-885.

Magasanik, B. (1961). Catabolite repression. Cold Spring Harbor Symp Quant Biol 26, 249-256.

Martin, S. A. \& Russell, J. B. (1986). Phosphoenolpyruvate-dependent phosphorylation of hexoses by rumen bacteria: evidence for the phosphotransferase system of transport. Appl Environ Microbiol 52, 1348-1352.

Martin, S. A. \& Russell, J. B. (1987). Transport and phosphorylation of disaccharides by the ruminal bacterium, Streptococcus bovis. Appl Environ Microbiol 53, 2388-2393.

Monod, J. (1947). The phenomenon of enzymatic adaptation. Growth 11, 223-289.

Peterkofsky, A. \& Gazdar, C. (1974). Glucose inhibition of adenylate cyclase in intact cells of E. coli B. Proc Natl Acad Sci US A 71, 2324-2328.

Postma, P. W., Lengeler, J. W. \& Jacobson, G. R. (1993). Phosphoenolpyruvate:carbohydrate phosphotransferase systems of bacteria. Microbiol Rev 57, 543-594.

Reizer, J. (1989). Regulation of sugar uptake and efflux in Grampositive bacteria. FEMS Microbiol Rev 63, 149-156. 
Reizer, J. \& Panos, C. (1980). Regulation of $\beta$-galactoside phosphate accumulation in Streptococcus pyogenes by an expulsion mechanism. Proc Natl Acad Sci US A 77, 5497-5501.

Reizer, J. \& Peterkofsky, A. (1987). Regulatory mechanism for sugar transport in Gram-positive bacteria. In Sugar Transport and Metabolism in Gram-positive Bacteria, pp. 333-364. Edited by J. Reizer \& A. Peterkofsky. Chichester: Ellis Horwood.

Reizer, J., Novotny, M. J., Panos, C. \& Saier, M. H., Jr (1983). Mechanism of inducer expulsion in Streptococcus pyogenes: a two-step process activated by ATP. J Bacteriol 156, 354-361.

Reizer, J., Novotny, M. J., Hengstenberg, W. \& Saier, M. H., Jr (1984). Properties of ATP-dependent protein kinase from Streptococcus pyogenes that phosphorylates a seryl residue in $\mathrm{HPr}$, a phosphocarrier protein of the phosphotransferase system. J Bacteriol $160,333-340$.

Reizer, J., Deutscher, J., Sutrina, S., Thompson, J. \& Saier, M. H., Jr (1985). Sugar accumulation in Gram-positive bacteria: exclusion and expulsion mechanisms. Trends Biochem Sci 1, 32-35.

Reizer, J., Peterkofsky, A. \& Romano, A. H. (1988). Evidence for the presence of heat-stable protein $(\mathrm{HPr})$ and ATP-dependent $\mathrm{HPr}$ kinase in heterofermentative lactobacilli lacking phosphoenolpyruvate: glucose phosphotransferase activity. Proc Natl Acad Sci US A 85, 2041-2045.

Reizer, J., Sutrina, S. L., Saier, M. H., Jr, Stewart, G. C., Peterkofsky, A. \& Reddy, A. P. (1989). Mechanistic and physiological consequences of $\mathrm{HPr}(\mathrm{ser})$ phosphorylation on the activities of the phosphoenolpyruvate: sugar phosphotransferase system in Gram-positive bacteria: studies with site-specific mutants of HPr. EMBO J 8, 2111-2120.

Reynolds, J. G., Silva, E. \& McCormack, W. M. (1983). Association of Streptococcus bovis bacteremia with bowel disease. J Clin Microbiol 17, 696-697.

Russell, J. B. (1990). Low-affinity, high-capacity system of glucose transport in the ruminal bacterium Streptococcus bovis: evidence for a mechanism of facilitated diffusion. Appl Environ Microbiol 56, 3304-3307.

Russell, J. B. \& Robinson, P. H. (1984). Compositions and characteristics of strains of Streptococcus bovis. J Dairy Sci 67, 1525-1531.

Russell, J. B., Strobel, H. J., Driessen, A. J. M. \& Konings, W. N. (1988). Sodium dependent transport of neutral amino acids by whole cells and membrane vesicles of Streptococcus bovis, a ruminal bacterium. J Bacteriol 170, 3531-3536.

Saier, M. H., Jr (1985). Mechanisms and regulation of carbohydrate transport in bacteria. Academic Press, Orlando, Fl.

Saier, M. H., Jr (1989). Protein phosphorylation and allosteric control of inducer exclusion and catabolite repression by the bacterial phosphoenolpyruvate:sugar phosphotransferase system. Microbiol Rev 53, 109-120.

Saier, M. H., Jr \& Roseman, S. (1976). Sugar transport. Inducer exclusion and regulation of the melibiose, maltose, glycerol and lactose transport systems by the phosphoenolpyruvate:sugar phosphotransferase system. J Biol Chem 249, 6606-6615.

Slyter, L. L. (1976). Influence of acidosis on rumen function. $J$ Anim Sci 43, 910-929.

Sutrina, S. L., Reizer, J. \& Saier, M. H., Jr (1988). Inducer expulsion in Streptococcus pyogenes: properties and mechanism of the efflux reaction. J Bacteriol 170, 1874-1877.

Thompson, J. \& Chassy, B. M. (1983a). Novel phosphoenolpyruvate-dependent futile cycle in Streptococcus lactis: 2-deoxy-Dglucose uncouples energy production from growth. J Bacteriol 151, 1454-1465.

Thompson, J. \& Chassy, B. M. (1983b). Intracellular hexose-6phosphate: phosphohydrolase from Streptococcus lactis: purification, properties and function. $J$ Bacteriol 156, 70-80.

Thompson, J. \& Saier, M. H., Jr (1981). Regulation of methyl- $\beta$-Dthiogalactopyranoside-6-phosphate accumulation in Streptococcus lactis by exclusion and expulsion mechanisms. J Bacteriol 146, 885-894.

Winkler, H. H. (1991). Efflux and the steady state in $\alpha$ methylglucoside transport in Escherichia coli. J Bacteriol 106, 362-368.

Ye, J. J., Reizer, J., Cui, X. \& Saier, M. H., Jr (1994). Inhibition of the phosphoenolpyruvate: lactose phosphotransferase system and activation of a cytoplasmic sugar-phosphate phosphatase in Lactococcus lactis by ATP-dependent metabolite-activated phosphorylation of serine HPr in the phosphocarrier protein HPr. $J$ Biol Chem 269, 11837-11844.

Received 16 February 1995; revised 12 May 1995; accepted 30 May 1995. 